\title{
The Local Wisdom Value of Folklore In The Indonesian Textbook for Senior High School Student
}

\author{
Listya Buana Putra ${ }^{1}$, Sarwiji Suwandi ${ }^{2}$ Andayani $^{3}$ \\ 1, 2,3 Universitas Sebelas Maret, Surakarta, Indonesia \\ ${ }^{1}$ listyabuana@student.uns.ac.id, 22sarwijiswan@yahoo.com, \\ 3bu_anda09@yahoo.co.id
}

\begin{abstract}
Nowadays, local wisdom attracts international attention. Local wisdom includes various things about the diversity of values, customs, and culture. The purpose of this study was to determine the value of local wisdom folklore texts in theIndonesian textbook for ten grade senior high school students. The values of local wisdom are elaborated as follows: (1) the religious values (religion), (2) the social values, (3) the moral values, (4) the leadership values, (5) the exemplary/heroic values, (6) the traditional and cultural values, and (7) thedevotion value. The object of this studywas the Indonesian textbook for ten grade senior high school students- folklore text. The results of the study showed that the Indonesian textbook for senior high school contains local wisdom value. By understanding the local wisdom value it is hoped that students can internalize and take the values from it. The approach used in this research was the critical discourse analysis approach.
\end{abstract}

Keywords: local wisdom, values, folklore

\section{INTRODUCTION}

Local wisdom has a variety of terms, including local genius (HG Quaritch Wales), cultural identity or national cultural personality (Haryati Soebadio), local cultural personality (Mundardjito), cultural light/cerlang budaya (Ayatrohaedi), national identity, cultural identity (Soediman), indigenous knowledge (Semali \& Kincheloe). Definitively, local wisdom is interpreted as all forms of knowledge, beliefs, understandings, or insights as well as customs or ethics that guide human behavior in life in the ecological community [1].

Local wisdom or "local genius" is a term introduced by Wales in Ayatrohaedi which means " the sum of the cultural characteristics which the vast majority of people have in common as a result of their experiences in early life " [2]. The Indonesian thesaurus puts the word wisdom in line with virtue, policy, wisdom and scholarship. While the word arif has equality of meanings with: smart, virtuous, bakir, bestari, wise, wise, smart, smart, smart, smart, energetic, smart, 
intelligent, smart, and learned [3]. According to Rahyono, local wisdom is human intelligence possessed by certain ethnic groups obtained through the community experience [4]. Naritoom [5] formulates local wisdom with the definition, "Local wisdom is the knowledge that was discovered or acquired by local people through the accumulation of experiences in trials and integrated with the understanding of surrounding nature and culture. Local wisdom is dynamic by the function of created local wisdom and connected to the global situation."

"Local wisdom is part of culture. Local wisdom is traditional culture elements that are deeply rooted in human life and community that are related to human resources, source of culture, economic, security and law. Local wisdom can be viewed as a tradition that is related to farming activities, livestock, build house etc " [6]. Local wisdom are values that are created, developed and maintained within the local community and for its ability to survive and become a guideline of life in society. Local wisdom includes various mechanisms and ways to behave, behave and act as outlined in the social order. Local wisdom is all local intelligences that are transformed into inventions, works and initiatives so that the community can be independent in a changing social climate. Copyright, work and intention are also called culture. Local wisdom has six (6) dimensions, namely: (1) the local knowledge, (2) the local value, (3) the local skills, (4) the local resources, (5) the mechanism of local decision-making, (6) the solidarity of local group [7].

A similar study that has been reviewed is titled "The Value of Local Wisdom in Japanese Folklore (Minwa)". In that research it was explained that the values of local wisdom of a nation can be found among others in the folklore of the nation concerned. There are many values of wisdom in folklore, especially minwa. One of them is the value of returning the favor or ongaaeshi [8]. The research gaps found were that in the research above the folklore that was discussed was only one type (title), whereas in this study the folklore discussed there were various types (title). This means that researchers can compare the values contained in various folklore titles being studied.

The Indonesian Textbooks for High School is one learning material which contains local wisdom content, namely folklore text material. This folklore text material always contains stories or lessons that can be emulated by readers. Because of this reason, it is interested tostudy the dimensions of local wisdom contained in the folklore text material in the Indonesian Textbooks for High School. The folklore is interpreted as an oral culture of traditional society which is spread in a relatively fixed form, spread among certain collectives over a long period of time using cliché words, and has a role as education media, solace, social protest, and projection latent desires [9]. There are many type of Folklore. They are legends, fables, fables, stories, and many others. In this study, It will be focused on just one type of folklore - saga. A saga is a classic Malay folklore, which has the characteristics of a semi-Malay Indonesian language and, it has a centric palace background, has the characteristics of the magic of its characters, and is fictional.

Wright \& Hope [10] provides a very fundamental definition that a textbook is a collection of material that is arranged in detail, sequentially, and contains one particular field of science. In addition, textbooks are also designed with practical principles and are easy to understand (must have a high level of readability). With the insertion of the value of local wisdom in Indonesian textbooks, it will complement the treasures, insights, and knowledge in the Indonesian language field. 


\section{METHOD}

The approach used in this research was the critical discourse analysis approach. The method used was the content analysis method. While the data examined was saga texts contained in the Indonesian textbook for ten grade senior high school students. The sampling technique used in this study was purposive sampling technique. The purposive sampling technique is the technique of determining the sample with certain considerations [11]. There are five saga titles in Indonesian textbook for ten grade senior high school students. They are "Indera Bangsawan”, "Bayan Budiman", "Bunga Kemuning", "Tukang Pijit Keliling", and "Si Miskin”.

\section{RESULTS AND DISCUSSION}

The analysis of data from five saga texts in Indonesian textbook for ten grade senior high school studentsobtained local wisdom values in the form of the religious values, the social values, the moral values, and the exemplary/heroic values. The following discussion of local wisdom value can be found in folklore text material.

\subsection{The Local Wisdom Value in the Saga of Indera Bangsawan}

The local wisdom value in the Saga of Indera Bangsawan consists of religious, social, and moral values. The religious value is described in the main figure's life. Everyone should always hold the principle and believe to AllahSubhanahu wata'ala. This aims to remind us not to be arrogant after success and hopeless when fail. The following is the citation:"Said the Syah Peri's words who has broken up with his relative, Indera Bangsawan. So he surrendered himself to Allah Subhanahu wata'ala and face the facts strongly." (Suherli, 2017: 109)

The social value is seen from the figure of the giant grandma who sincerely help Indera Bangsawan. The grandma gives a green house and teaches Indera Bangsawan to take a giant robe. The following is the citation: "Therefore, the giant grandma teaches Indera Bangsawan. Indera Bangsawan is given a green house and taught how to take the giant robe..." (Suherli, 2017: 110)

The moral value is seen from the figures attitude of shyness. The shyness has to be internalized because this will save someone from greediness. The following is the citation: "They are shy if the bad intention of lie is known by the king and his people." (Suherli, 2017: 110)

\subsection{The local wisdom value in the Saga of Bayan Budiman}

The local wisdom value in the saga of Bayan Budiman consists of religious and dedicative value. The religious value is seen from the figure behavior who is patient while praying. Like the figure of Saudagar Mubarok and his wife that is patient while praying until they have a baby. "Not a long time after praying, Saudagar Mubarok and his wife have a baby boy named Khojan Maimun.” (Suherli, 2017: 120) 
The dedicative value is shown by Si Burung Bayan who saves his wife. His wife almost fallen out on cheating with the prince. Bayan is willing to be the story teller to his king's wife so that she will not go away, and she saves from cheating.

"The wise Bayan does not only save himself but also save his king's wife to be loyal to her husband. He can also save the name of his king and his family".

\subsection{The local wisdom in the Saga of Bunga Kemuning}

The local wisdom values shown from the attitude of putri kuning are humble, independent, and friendly. Even though Putrid Kuning was so beautiful, she was independent and kind. She was an obedient girl and loves to help everyone.

"even though their beauty was almost similar, the last child Putri Kuning was a little bit different. She was independent and kind. She wascheerful and smile friendly to everyone. She likes to go and play with her caregiver than her sisters." (Suherli, 2017: 117)

The exemplary/heroic value is shown from Putri Kuning's attitude who is always clean the garden. Although she is a princess, she is so kind-hearted. She is not shy to do all house work (palace).

"Putri Kuning take the broom and start to clean the garden. She fell the dry leaves, lift the weeds, and cut the branches neatly. At first the caregiver forbade her, but Putri Kuning persistently do it." (Suherli, 2017: 117)

\subsection{The Local Wisdom Value in the Saga of Tukang Pijit Keliling}

The national value is shown in the saga of Tukang Pijit Keliling. The integrity and sincerity is the social value that is almost faded. Therefore, the social value is shown in the saga of Tukang Pijit Keliling. Integrity and sincerity is the social value that is almost faded. Therefore, this behavior must be always fostered by everyone. Like done by Darko, if there is someone needs him he will immediately help the person sincerely.

"And if there is someone dead, Darko often helps the gravediggers even though only takes water from well so that the soil is easily dug." (Suherli, 2017: 135)

\subsection{The Local Wisdom Value in Saga of Si Miskin}

The social value is shown from the king's attitude who safe the poor from people's tantrum. The king then drove the people out so that they will not persecute the poor. The king's order, "what's out there?" and people say "my lord, people throw the poor". So the king ordered, "Drive the poor away!" So he is driven out until he is arrived in the beach. People go back to the palace.

From the finding above, it is explained that the local wisdom value contained in the text if folklore in the material book of tenth graders of senior high school consist of religious, moral, social, and heroic values. All the values is relevant with nowadays life where the values implemented will give the benefits for youth generation. Therefore, it is appropriate of the material book of Indonesian Language is inserted by the local wisdom value. In line with the study of Martawijayastates that the student's physics book based on local wisdom occupies a strategic 
position in learning to improve the character and completeness of student learning [12]. Next, Sudiana, I Made \& Sudirgayasa, I Gede stated that there are many Balinese local wisdoms that can be integrated in elementary school education and a draft textbook arranged quite well so it is feasible to apply [13]. If compared, so subject of this study is different with the study conducted by Purnomowulan, et al. seen from the subject. In this study the subject is senior high school students while in Purnomowulan's study the subject is the foreign speaker. Therefore, the material scope is also different. This study the material scope is the Indonesian language book of folklore material while in the Purnomowulan's the scope is in the material of Indonesian language generally [14].

\section{CONCLUSION}

The folklore text in the Indonesian textbook for ten grade senior high school studentshas fulfilled the criteria of local wisdom value. This needs to be kept up and for the improvement of education Indonesia. By understanding the local wisdom value it is hoped that students can internalize and take the values from it. It is crucial as the local wisdom a value nowadays is crushed with the western negative value.

\section{REFERENCES}

[1]. Keraf, A. S. Etika Lingkungan Hidup. Jakarta: Penerbit Buku Kompas. 2010.

[2]. Ayatrohaedi. Kepribadian Budaya Bangsa (Local Genius). Jakarta: Pustaka Pelajar. 1986.

[3]. Sugono, D., Sugiyono, \& Qudaratillah, M. T. Tesaurus Bahasa Indonesia. Jakarta: Pusat Bahasa Departemen Pendidikan Nasional. 2008.

[4]. Rahyono, F. X. Kearifan Budaya dalam Kata. Jakarta: Wedatama Widya Sastra. 2009.

[5]. Wagiran. Pengembangan Model Pendidikan Kearifan Lokal dalam Mendukung Visi Pembangunan Provinsi Daerah Istimewa Yogyakarta Menuju 2020 (Tahun Kedua), Jurnal Penelitian dan Pengembangan, Vol. III, No. 3, pp. 85 - 100, 2010.

[6]. Geertz, C. The Interpretation of Cultures. New York: Basic Books, Inc., Publishers. 1973.

[7]. Ife, Jim. Community Development: Creating Community Alternatives-Vision, Analysis and Practice. Australia: Longman. 1995.

[8]. Asri, A. S. Telaah Buku Teks Pegangan Guru dan Siswa pada Mata Pelajaran Bahasa Indonesia Kelas VII Berbasis Kurikulum 2013, Retorika: Jurnal Ilmu Bahasa, Vol. 3, No. 1, pp. 70 - 82, 2017.

[9]. Danandjaja, J. Folklor Indonesia, Ilmu Gosip, Dongeng, dan Lain-lain. Jakarta: Grafiti. 2002.

[10]. Wright, L. \& Hope, J. Stylistics A Practical Coursebook. London \& New York: Routledge. 1996.

[11]. Sugiyono. Metode Penelitian Kuantitatif, Kualitatif, dan R \& D. Bandung: Penerbit Alfabeta. 2009.

[12]. Martawijaya, M. A. Physics Book of Students Based on Local Life to Improve Character and Learning Competition, Jurnal Sains dan Pendidikan Fisika, Vol. 10, No. 3, pp. 285- 292, 2014.

[13]. Sudiana, I Made \& Sudirgayasa, I Gede. Integration of Bali Local Wisdom in Elementary School Textbooks, Jurnal Kajian Bali, Vol. 05, No. 01, pp. 181 - 200, 2015.

[14]. K. Saddhono, "Cultural and Social Change of Foreign Students in Indonesia: The Influence of Javanese Culture in Teaching Indonesian to Speakers of Other Languages (TISOL)," in IOP Conference Series: Earth and Environmental Science, 2018, vol. 126, no. 1. 